\title{
Quantification of crop weather relationship and the effect of different planting dates on growth and yield of potato cultivars in a sub-tropical environment at Hisar
}

\section{Yogesh Kumar* \\ Department of Agricultural Meteorology,College of Agriculture,CCS Haryana Agricultural University, Hisar-125004 (Haryana), India}

Raj Singh

Department of Agricultural Meteorology,College of Agriculture,CCS Haryana Agricultura University, Hisar-125004 (Haryana), India

\section{Anil Kumar}

Department of Agricultural Meteorology,College of Agriculture,CCS Haryana Agricultura University, Hisar-125004 (Haryana), India

\section{S. Dagar}

Department of Agricultural Meteorology,College of Agriculture,CCS Haryana Agricultural University, Hisar-125004 (Haryana), India

*Corresponding author. E-mail: yogeshgujjar62@gmail.com

\begin{abstract}
Field experiments were carried out at research farm of Department of Agricultural Meteorology, CCSHAU, Hisar during Rabi seasons of 2016-17 to quantify crop weather relationship and the effect of different planting dates on growth and yield of potato cultivars in a sub-tropical environment at Hisar. The experimental field was adjacent to Agrometeorological observatory at $29^{\circ} 10^{\prime} \mathrm{N}$ latitude, $75^{\circ} 46^{\prime} \mathrm{E}$ longitude and altitude of 215.2 $\mathrm{m}$. The main plots treatments consisted four date of sowing viz. $D_{1}-8^{\text {th }}$ Oct., $D_{2}-22^{\text {th }}$ Oct., $D_{3}-5^{\text {th }}$ Nov. and $D_{4}-23^{\text {rd }}$ Nov. The sub-plots treatment consisted of three varieties $\left(V_{1}\right.$ Kufri Bahar, $V_{2}$ - Kufri Pushkar and $V_{3}$ - Kufri Surya). The forty eight treatment combinations were tested in split plot design with four replications. The results revealed that various growth and yield observations were recorded higher in second sown crop $\left(22^{\text {th }}\right.$ Oct.) as followed by other planting dates. The maximum tuber yield were produced in $D_{2}(20810.45 \mathrm{~kg} / \mathrm{ha})$ and it was least in $D_{4}(14525.46 \mathrm{~kg} / \mathrm{ha})$. Among the varieties, Kufri Pushkar recorded highest tuber yield $(21478.06 \mathrm{~kg} / \mathrm{ha})$ followed by Kufri Bahar $(17432.26 \mathrm{~kg} / \mathrm{ha})$ and Kufri Surya $(15378.11 \mathrm{~kg} / \mathrm{ha})$. In crop weather relationship, Tuber yield and plant height were significantly positively correlated with rainfall $(0.80$ and 0.92$)$ and rainy days $(0.50$ and 0.53$)$. Evening relative humidity was also positively correlated with LAI (0.59) and tuber yield (0.78) of potato. Vegetables production is considered to be particularly important in satisfying world food demand. Specific research therefore is needed in order to evaluate the effects of environmental factors that crop encounters during its growth period and its production.
\end{abstract}

Keywords: Crop-weather relationship, Growth parameters, LAI, Planting dates, Yield attributes

\section{INTRODUCTION}

The potato (Solanum tuberosum L.) is the third most important food crop in the world after rice and wheat and consumed by more than a billion people worldwide. Globally potato is cultivated on 19.3 million ha with an annual production of around 368 million tons (FAOSTAT, 2014). India's potato production has exploded since the middle of the $20^{\text {th }}$ century, increasing by $850 \%$ from 1960 to 2000 . It is cultivated over an area of approximately 2124.41 lakh ha with a production of 48604.57 metric ton and productivity 21.51 metric ton per hectares. In Haryana, potato is cultivated

\section{Article Info}

DOI:10.31018/jans.v11i1.1965

Received: December 9, 2018

Revised: January 20, 2019

Accepted: January 24, 2019

\section{How to Cite}

Kumar. Y. et al. (2019). Quantification of crop weather relationship and the effect of different planting dates on growth and yield of potato cultivars in a sub-tropical environment at Hisar. Journal of Applied and Natural Science, 11 (1): 17 - 22 
portant food for the increasing world population, and has the potential for fulfilling vitamin $C$ and protein content requirement. Meteorological elements governing growth, development, production and quality of potato tubers at a given site are basically air and soil temperatures, solar radiation, photoperiod, soil moisture and evapotranspiration. Potato is best adapted to cool climates such as tropical region with mean daily temperatures varied from $15^{\circ} \mathrm{C}$ to $18^{\circ} \mathrm{C}$. Higher temperatures favour foliar development and retard tuberization. In addition, heat stress leads to a higher number of smaller tubers per plant; lower tuber specific gravity with reduced dry matter content, and usually to a paler skin color of the tubers (Haverkort, 1990). Planting time may affect crop growth and yield in sub-tropical regions, where high temperature and drought stress are common during late crop development and maturation during Rabi season (Thongam et al. 2017). Earlier planting may expose the crop to higher temperature at reproductive stage while late planting may result in low biomass production and affect tuber development due to higher temperature conditions at maturity of Rabi crops including potato. The crop management practices, such as changing planting date or selection of variety modifying plant duration will affect potential yield. Potato varieties have divergence for morphological, physiological and yield potential that allow them to respond differently to planting environment is another factor that may affect the growth and yield of potato. Therefore, this study was planned to investigate the effect of planting dates and varieties interaction on growth and yield of potato, and also to quantify cropweather relationships in sub-tropical environment at Hisar.

\section{MATERIALS AND METHODS}

An experiment was conducted in Rabi season of year 2016-17 research farm, Department of Agricultural Meteorology, CCSHAU Hisar, Haryana. The field area was adjacent to Agrometeorological observatory at $29^{\circ} 10^{\prime} \mathrm{N}$ latitude, $75^{\circ} 46^{\prime} \mathrm{E}$ longitude and altitude of $215.2 \mathrm{~m}$. The main plots treatments consisted four planting dates viz. $D_{1}-8^{\text {th }}$ Oct., $D_{2}-22^{\text {th }}$ Oct., $D_{3}-5^{\text {th }}$ Nov. and $D_{4}-23^{\text {rd }}$ Nov. The sub-plots consisted of three varieties $\left(\mathrm{V}_{1}-\right.$ Kufri Bahar, $\mathrm{V}_{2}-$ Kufri Pushkar and $\mathrm{V}_{3}$ - Kufri Surya). The size of net and gross plot in experimental field was $5.0 \times 3.6 \mathrm{~m}^{2}$ and $6.0 \times 4.8$ $\mathrm{m}^{2}$. The forty eight treatment combinations were tested in split plot design with four replications. Various growth observations were observed as follows:

Plant height: Plant height was measured at various phenophases from emergence to physiological maturity on five tagged plants in each plot. The height was measured from the base of the plant to the tip of the main stem of randomly tagged plants and expressed in centimeters $(\mathrm{cm})$ and their mean values were calculated.

Number of leaves per plant: The number of leaves per plant was counted at various phenophases from emergence to physiological maturity on five tagged plants in each plot. The numbers of leaves per plant were determined by counting all leaves of randomly tagged plants and their mean values were calculated.

Leaf area index (LAI): The plant leaves separated from samples taken for dry matter were used for determining leaf area from each plot at 15 days interval after sowing; starting from emergence till physiological maturity. The green leaf area $\left(\mathrm{cm}^{2}\right)$ was recorded using leaf area meter (LI-3000 Area meter, LI-COR Biosciences, Nebraska, USA). The leaf area measured with the help of leaf area meter was used to compute the LAl by the following formula.

$$
\text { LAI }=\frac{\text { Leaf area }\left(\mathrm{cm}^{2}\right)}{\text { Land area covered by plant }\left(\mathrm{cm}^{2}\right)}
$$

Dry matter accumulation: The five randomly selected plants from destructive sampling were used to record the dry matter production at different phenological stages after planting times to physiological maturity. The sampled plants were separated into roots, stems, leaves and reproductive parts (Stolon and Tuber) and sun dried. Further, the samples were oven dried at $65^{\circ} \mathrm{C}$ to 70 ${ }^{\circ} \mathrm{C}$ to a constant weight. The dry matter accumulation in different plant parts was converted to gram per plant.

\section{Yield and yield attributes}

Number of tubers per plant: The numbers of tubers per plant were calculated at harvest by average values of five plants harvested for biomass observation in all the treatments.

Tuber weight (g per tuber weight): After digging, a random sample of tuber weight was taken from each plot. From these samples, randomly 10 tubers were selected for each plot for weighing with the help of the weighing (g) machine was taken with electronic balance.

Tuber yield (kg ha ${ }^{-1}$ ): After digging, a random sample of tuber weight was taken from each plot. From these samples, randomly 10 tubers were selected for each plot for weighing with the help of the weighing $(\mathrm{g})$ machine was taken with electronic balance. The tuber yield per plant from net plot was weighed on top pan balance and converted into $\mathrm{kg} \mathrm{ha}^{-1}$.

Haulm yield $\left(\mathbf{k g ~ h a}^{-1}\right)$ : The biological yield was obtained by summing up the weight of total tuber yield and weight of haulm of each net plot. Then the values were converted into $\mathrm{kg} \mathrm{ha}^{-1}$.

Harvest index (HI, \%): The harvest index was calculated by dividing the economic yield (total tuber yield) with total biological yield per net plot and then expressed as percent. 
Harvest index $(\%)=\frac{\text { Economic yield per plot }}{\text { Biological vield per plot (economic vield }+ \text { follaqe weight) }} \times 100$

\section{RESULTS AND DISCUSSION}

Weather conditions during Rabi 2016-17: The weekly mean maximum temperature during Rabi season $2016-17\left(40^{\text {th }}\right.$ to $6^{\text {th }}$ SMW (Standard Meteorological Week) i.e. $1^{\text {st }}$ Oct 2016 to $15^{\text {th }}$ April, 2017) varied between 16.9 to $42.9{ }^{\circ} \mathrm{C}$, whereas the weekly mean minimum temperature of Hisar region ranged from 3.2 to $24.7{ }^{\circ} \mathrm{C}$. The mean maximum temperature was slightly above normal during most of the season with weekly average deviation of $+1.1^{\circ} \mathrm{C}$ from normal. The mean minimum temperature during the whole Rabi season was slightly above normal. The average deviation for the season was $+1.6{ }^{\circ} \mathrm{C}$ while the maximum deviation was $5.7{ }^{\circ} \mathrm{C}$ from normal in $40^{\text {th }} \mathrm{SMW}$ (1$7^{\text {th }}$ Oct. 2016). The weekly maximum temperature

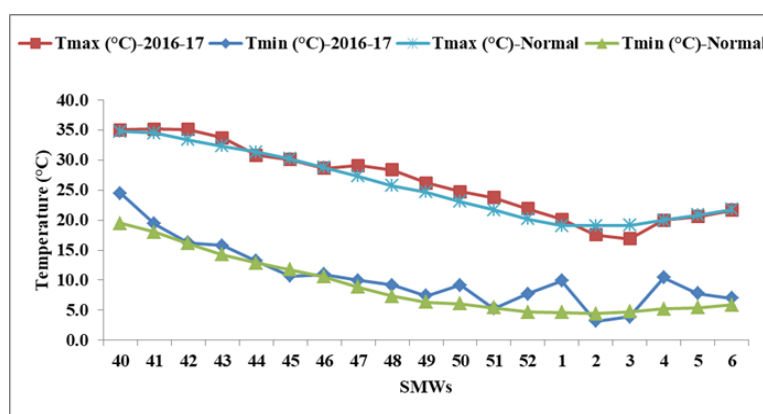

Fig. 1. Maximum and minimum temperature $\left({ }^{\circ} \mathrm{C}\right)$ along with normal during Rabi 2016-17.

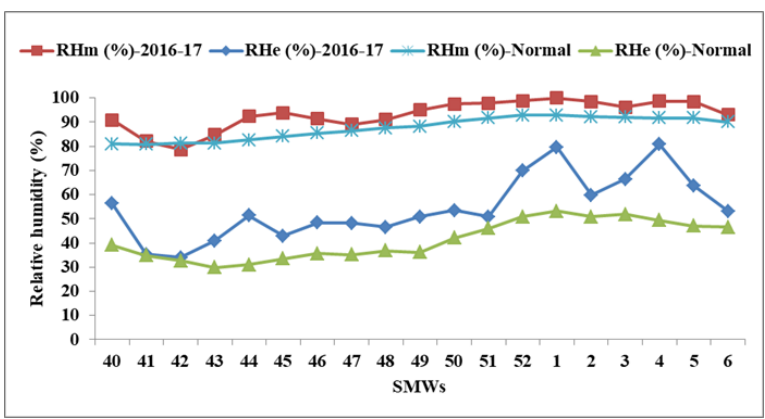

Fig. 2. Morning and evening relative humidity (\%) along with normal during Rabi 2016-17. was highest in $16^{\text {th }} \operatorname{SMW}\left(42.9^{\circ} \mathrm{C}\right)$ and lowest in $3^{\text {rd }} \mathrm{SMW}\left(16.9{ }^{\circ} \mathrm{C}\right)$ during the season, whereas weekly minimum temperature was highest in $16^{\text {th }}$ $\operatorname{SMW}\left(24.7^{\circ} \mathrm{C}\right)$ and lowest in $2^{\text {nd }} \operatorname{SMW}\left(3.2^{\circ} \mathrm{C}\right)$ during the season (Fig. 1).

The mean weekly morning relative humidity values were ranged from 45 to $100 \%$ and the evening relative humidity were ranged between 16 and 81 $\%$ shown in the Fig 2. For most of season $\mathrm{RH}$ (morning as well as evening) remained higher than normal and declined to normal values in February 2017. The weekly bright sunshine hours (BSS) ranged between 2.5 to 10.3 hour/day with seasonal average of 7 hour/day (Fig. 3). The average pan evaporation $(2.9 \mathrm{~mm} /$ day) recorded during $\mathrm{Rabi}$ season was below the normal throughout the season.

During Rabi season, 2016-17, $60.7 \mathrm{~mm}$ rainfall with 6 rainy days (Maximum 4 rainy days in Jan.) was recorded at Hisar. Highest rainfall $(34.6 \mathrm{~mm})$

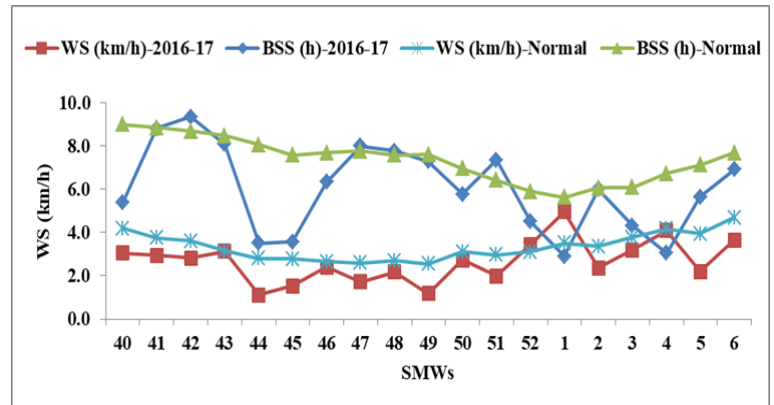

Fig. 3. Wind speed (WS) and bright sunshine hours (BSS) along with normal during Rabi 2016-17.

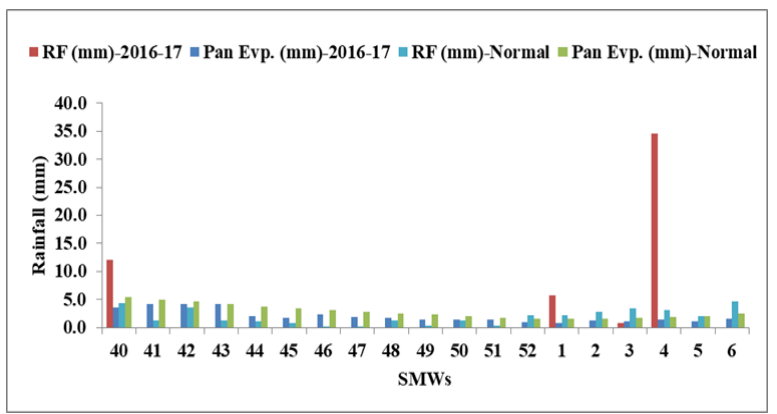

Fig. 4. Rainfall (rain) and pan evaporation (PE) during Rabi 2016-17.

Table 1. Effect of planting dates on plant height of potato cultivars.

\begin{tabular}{|c|c|c|c|c|c|}
\hline \multirow{2}{*}{ Treatment } & \multicolumn{5}{|c|}{ Plant height $(\mathrm{cm})$} \\
\hline & Emergence & Stolonization & Tuber initiation & Tuber bulking & Physiological maturity \\
\hline \multicolumn{6}{|c|}{ Main-plot treatment } \\
\hline $\mathrm{D}_{1}$ & 11.52 & 21.91 & 30.14 & 35.74 & 41.32 \\
\hline$D_{2}$ & 16.03 & 23.53 & 35.26 & 40.23 & 43.86 \\
\hline$D_{3}$ & 10.45 & 18.96 & 28.86 & 34.00 & 36.91 \\
\hline $\mathrm{D}_{4}$ & 9.33 & 15.45 & 26.25 & 31.73 & 33.23 \\
\hline CD at $5 \%$ & 1.07 & 2.60 & 1.62 & 4.34 & 3.40 \\
\hline \multicolumn{6}{|c|}{ Sub-plot treatment } \\
\hline K. Bahar & 11.76 & 20.65 & 30.22 & 35.96 & 38.46 \\
\hline K. Pushkar & 13.63 & 21.86 & 33.20 & 41.93 & 43.13 \\
\hline K. Surya & 10.14 & 17.36 & 26.86 & 29.96 & 35.06 \\
\hline CD at $5 \%$ & 0.34 & 1.52 & 0.97 & 1.84 & 1.29 \\
\hline
\end{tabular}


Kumar. Y. et al. / J. Appl. \& Nat. Sci. 11(1): 17 - 22 (2019)

Table 2. Effect of planting dates on number of leaves per plant of potato cultivars.

\begin{tabular}{|c|c|c|c|c|c|}
\hline \multirow{2}{*}{ Treatment } & \multicolumn{5}{|c|}{ No of leaves per plant } \\
\hline & Emergence & Stolonization & Tuber initiation & Tuber bulking & Physiological maturity \\
\hline \multicolumn{6}{|c|}{ Main-plot treatment } \\
\hline $\mathrm{D}_{1}$ & 14.7 & 49.3 & 106.5 & 146.3 & 122.9 \\
\hline$D_{2}$ & 17.8 & 59.5 & 120.7 & 163.9 & 133.1 \\
\hline$D_{3}$ & 11.7 & 38.8 & 102.4 & 133.3 & 112.3 \\
\hline$D_{4}$ & 8.9 & 31.2 & 92.3 & 113.8 & 102.3 \\
\hline CD at $5 \%$ & 1.46 & 4.78 & 6.45 & 18.6 & 14.8 \\
\hline \multicolumn{6}{|c|}{ Sub-plot treatment } \\
\hline K. Bahar & 13.4 & 46.0 & 109.9 & 136.9 & 120.1 \\
\hline K. Pushkar & 16.2 & 53.3 & 114.8 & 164.4 & 129.3 \\
\hline K. Surya & 10.2 & 34.8 & 91.8 & 116.6 & 103.5 \\
\hline CD at $5 \%$ & 0.91 & 4.04 & 3.75 & 12.3 & 5.48 \\
\hline
\end{tabular}

Table 3. Effect of planting dates on leaf area index (LAI) of potato cultivars.

\begin{tabular}{llllll}
\hline \multirow{2}{*}{ Treatment } & \multicolumn{5}{c}{ LAl } \\
\cline { 2 - 6 } & Emergence & Stolonization & Tuber initiation & Tuber bulking & Physiological maturity \\
\hline \multicolumn{2}{l}{ Main-plot treatment } & & & 3.43 & 1.65 \\
\hline $\mathrm{D}_{1}$ & 0.43 & 1.07 & 2.94 & 3.79 & 2.12 \\
$\mathrm{D}_{2}$ & 0.63 & 1.43 & 3.45 & 3.01 & 1.45 \\
$\mathrm{D}_{3}$ & 0.37 & 0.99 & 2.57 & 2.73 & 1.13 \\
$\mathrm{D}_{4}$ & 0.27 & 0.88 & 1.85 & $\mathbf{0 . 4 7}$ & $\mathbf{0 . 4 2}$ \\
$\mathrm{CD}$ at 5\% & $\mathbf{0 . 1 1}$ & $\mathbf{0 . 2 0}$ & $\mathbf{0 . 3 5}$ & 3.36 & 1.54 \\
\hline Sub-plot treatment & & & 3.91 & 2.12 \\
\hline K. Bahar & 0.45 & 1.10 & 2.66 & 2.46 & 1.02 \\
K. Pushkar & 0.59 & 1.44 & 3.40 & $\mathbf{0 . 1 5}$ \\
K. Surya & 0.22 & 0.74 & 2.04 & $\mathbf{0 . 2 1}$ & \\
CD at 5\% & $\mathbf{0 . 0 8}$ & $\mathbf{0 . 1 0}$ & $\mathbf{0 . 2 2}$ &
\end{tabular}

Table 4. Effect of planting dates on dry matter production of potato cultivars.

\begin{tabular}{|c|c|c|c|c|c|}
\hline \multirow{2}{*}{ Treatment } & \multicolumn{5}{|c|}{ Dry matter (gm/plant) } \\
\hline & Emergence & Stolonization & Tuber initiation & Tuber bulking & Physiological maturity \\
\hline \multicolumn{6}{|c|}{ Main-plot treatment } \\
\hline $\mathrm{D}_{1}$ & 1.10 & 4.25 & 8.96 & 12.24 & 18.10 \\
\hline$D_{2}$ & 1.31 & 4.93 & 10.02 & 13.31 & 20.68 \\
\hline$D_{3}$ & 0.86 & 3.41 & 7.90 & 10.78 & 15.79 \\
\hline $\mathrm{D}_{4}$ & 0.72 & 2.71 & 6.46 & 8.86 & 12.04 \\
\hline CD at $5 \%$ & 0.11 & 0.34 & 0.71 & 0.73 & 1.48 \\
\hline \multicolumn{6}{|c|}{ Sub-plot treatment } \\
\hline K. Bahar & 0.96 & 3.99 & 8.37 & 11.62 & 16.72 \\
\hline K. Pushkar & 1.29 & 4.46 & 9.42 & 13.13 & 20.20 \\
\hline K. Surya & 0.75 & 3.04 & 7.22 & 9.39 & 13.03 \\
\hline CD at $5 \%$ & 0.12 & 0.35 & 0.48 & 0.67 & 0.57 \\
\hline
\end{tabular}

Table 5. Effect of planting dates on yield and yield attributes of potato cultivars.

\begin{tabular}{llllll}
\hline Treatment & No of tubers/plant & Tuber weight (g/tuber) & $\begin{array}{l}\text { Tuber yield } \\
\text { (kg/ha) }\end{array}$ & $\begin{array}{l}\text { Haulm yield } \\
\text { (kg/ha) }\end{array}$ & $\begin{array}{l}\text { Harvest index } \\
\text { (\%) }\end{array}$ \\
\hline \multicolumn{2}{l}{ Main-plot treatment } & & & & \\
\hline $\mathrm{D}_{1}$ & 8.9 & 122.1 & 19711.80 & 39426.99 & 50.44 \\
$\mathrm{D}_{2}$ & 9.4 & 135.8 & 20810.45 & 40374.53 & 51.70 \\
$\mathrm{D}_{3}$ & 8.3 & 105.0 & 17336.86 & 37200.51 & 46.54 \\
$\mathrm{D}_{4}$ & 7.9 & 89.2 & 14525.46 & 35001.80 & 41.28 \\
CD at 5\% & $\mathbf{0 . 6 8}$ & $\mathbf{1 4 . 2 5}$ & $\mathbf{2 2 2 0 . 0 8}$ & $\mathbf{2 6 1 8 . 8 3}$ & $\mathbf{1 . 1 2}$ \\
\hline Sub-plot treatment & & & & \\
\hline K. Bahar & 8.49 & 115.07 & 17432.26 & 39025.29 & 44.60 \\
K. Pushkar & 10.29 & 118.13 & 21478.06 & 42566.04 & 50.63 \\
K. Surya & 7.09 & 105.81 & 15378.11 & 32411.55 & 47.23 \\
CD at 5\% & $\mathbf{0 . 4 1}$ & $\mathbf{1 0 . 0 2}$ & $\mathbf{1 2 3 7 . 5 9}$ & $\mathbf{2 1 1 9 . 0 4}$ & $\mathbf{0 . 9 7}$ \\
\hline
\end{tabular}

was recorded during the $4^{\text {th }} \mathrm{SMW}(22-28$ Jan.) of the season which helped in good Rabi crops production are depicted in the Fig. 4. The average monthly maximum temperature (Tmax) of Rabi
2016-17 season (October to February) were compared with last 30 year normal value and found that the Tmax slightly above to the normal (19722002) and deviation with the range between -1.0 
Kumar. Y. et al. / J. Appl. \& Nat. Sci. 11(1): 17 - 22 (2019)

Table 6. Correlation coefficient between weather variables and growth and yield parameters of potato.

\begin{tabular}{llllll}
\hline Weather variable & LAl & Dry matter & Tuber yield & Number of leaves/plant & Plant height \\
\hline Tmax & $\mathbf{- 0 . 6 4}$ & -0.35 & 0.03 & $\mathbf{- 0 . 6 2}$ & -0.42 \\
Tmin & $\mathbf{- 0 . 6 1}$ & -0.28 & 0.02 & $-\mathbf{0 . 6 0}$ & -0.39 \\
RHm & 0.50 & -0.07 & 0.49 & 0.35 & 0.04 \\
RHe & $\mathbf{0 . 5 9}$ & 0.00 & $\mathbf{0 . 7 8}$ & 0.43 & 0.13 \\
WS & 0.41 & $\mathbf{0 . 6 6}$ & $\mathbf{- 0 . 8 1}$ & $\mathbf{0 . 5 7}$ & $\mathbf{0 . 6 1}$ \\
SSH & -0.26 & 0.28 & $\mathbf{- 0 . 8 0}$ & -0.06 & 0.21 \\
PE & -0.40 & 0.29 & $\mathbf{- 0 . 6 6}$ & -0.19 & 0.14 \\
Rainfall & 0.49 & 0.49 & $\mathbf{0 . 8 0}$ & 0.47 & $\mathbf{0 . 5 0}$ \\
RD & 0.41 & $\mathbf{0 . 5 2}$ & $\mathbf{0 . 9 2}$ & 0.42 & $\mathbf{0 . 5 3}$ \\
\hline
\end{tabular}

Significant at $\mathrm{P}=0.05$, Tmax $=$ maximum temperature, Tmin $=$ minimum temperature, $\mathrm{RHm}=$ morning relative humidity, $\mathrm{RHe}=$ evening relative humidity, WS= wind speed, BSS= bright sunshine hours and Evap= rate of evaporation, $\mathrm{RD}=$ rainy day

to $2.0^{\circ} \mathrm{C}$ but in the month of January and February found near the normal and similarly lower value observed, which help to prolong the reproductive phase of Rabi season (Fig. 1). The average monthly minimum temperature (Tmin) of Rabi 2016-17 season were compared to normal and found that the Tmin were found above to the normal in the Rabi season and deviation with the range between 0.8 to $2.6^{\circ} \mathrm{C}$ but in the month of January and February found higher actual Tmin shown in the Fig 1.

Plant height: Plant height in different dates of planted crop and varieties showed significant differences (Table 1). Plant height gradually increased from the emergence to physiological maturity. Among the dates, $D_{2}$ recorded highest plant height $(43.8 \mathrm{~cm})$ at physiological maturity as compare to the other dates and it was lowest in $D_{4}$ planted crop $(33.2 \mathrm{~cm})$ due to low temperature during January and February which caused stunted plant growth, whereas, among the varieties, Kufri Pushkar recorded higher plant height (43.1 $\mathrm{cm})$. The results are conformation of the findings of Ezekiel and Bhargava (1997) at Central Potato Research Institute (CPRI), Shimla, Himachal Pradesh, who reported that plant height decreased with delayed planting in Kufri Bahar and Kufri Badshah when planted on 21 October, 5 November and 20 December, respectively. Modisane (2007) also concluded that plant height were higher in October sown potato crop instead of late sown in November at Pretoria, South Africa.

Number of leaves per plant: The number of leaves of potato increased from emergence to tuber bulking and decreased at physiological maturity due to leaf senescence (Table 2). Planting dates affected the number of leaves significantly in potato crop. Maximum numbers (17.8) of leaves were present in $D_{2}$ planting and minimum (8.9) in late planting i.e. $\mathrm{D}_{4}$. Among varieties, the maximum number (164.4) of leaves was in Kufri Pushkar and minimum (116.6) in Kufri Surya at tuber bulking stage. Thongam et al (2017) also reported that number of leaves per plant were more in $10^{\text {th }}$ October sown crop as compared to other dates in Maharashtra region. Khan et al. (2011) also ob- tained similar findings in potato for assessing growth and development of potato at Wageningen, Netherlands which strongly supports the results of the present investigation.

Leaf area index (LAI): The LAl increased gradually up to tuber bulking stage and decreased thereafter due to decrease in leaf number because of leaf senescence (Table 3 ). Among planting dates, maximum LAI (3.8) was attained in $22^{\text {th }}$ October as compared to other dates and this was poor in $3^{\text {rd }}$ and $4^{\text {th }}$ planting dates by low temperature during peak vegetative growth. The lowest LAI (2.7) was recorded under late planting i.e. $D_{4}$ because of the low temperature during January and February which caused burning of plant leaves in $D_{4}$. In present study, among varieties, Kufri Pushkar has shown higher value (3.9) of LAI as compared to Kufri Bahar (3.4) and Kufri Surya (2.5).

Dry matter production: Dry matter accumulations in different treatments were presented in the table 4 . Dry matter accumulation increased linearly from the emergence to physiological maturity. Among planting dates, highest dry matter was produced in $D_{2}$ as compared to the other dates. The highest dry matter $(20.68 \mathrm{~g} /$ plant) was recorded in $D_{2}$ planting and lowest (12.04 g/plant) was in $\mathrm{D}_{4}$ at physiological maturity. This was due to poor growth due to lower temperature which leads to burning of leaves in late sown crop. Among varieties, Kufri Pushkar recorded highest dry matter accumulation (20.20 g/plant) as compared to other varieties. Thongam et al (2017) also reported that dry matter accumulation were more in $10^{\text {th }}$ October sown crop followed by other dates and it was least in December in Maharashtra region.

Yield and yield attributes: The yield and yield attributes of potato cultivars influenced by planting dates during 2016-17 are presented in table 5 . Planting dates and varieties influenced the yield and yield attributes (number of tubers per plant, tuber weight, and tuber and haulm yield and harvest index) significantly at $5 \%$ level of significance. The delayed planting $\left(D_{3}\right.$ and $\left.D_{4}\right)$ had poor yield attributes along with the tuber yield and the differences were significant. Among planting date, 
higher number of tubers per plant (9.4) was recorded in $D_{2}$ planting whereas in case of varieties, higher number of tubers per plant (10.3) recorded in Kufri Pushkar. Tuber weight, tuber yield, haulm yield and harvest index were higher $(135.8 \mathrm{~g} /$ tuber, $20810.45 \mathrm{~kg} / \mathrm{ha}, 40374.53 \mathrm{~kg} / \mathrm{ha}$ and 51.70 $\%$, respectively) in $D_{2}$ planting as compared to other dates. This was due to comparatively unfavorable weather conditions during peak vegetative stage of $D_{3}$ and $D_{4}$. Thongam et al (2017) also reported that numbers of tubers per plant, tuber weight, tuber yield of potato were more in $10^{\text {th }}$ October planting dates as compared to other dates in Maharashtra region. Similar findings of tuber yield were also reported by Perumal (1981) in potato crop. Among varieties, tuber weight, tuber yield, haulm yield and harvest index were significantly higher in Kufri Pushkar (118.13 g, $21478.06 \mathrm{~kg} / \mathrm{ha}$ and $42566.04 \mathrm{~kg} / \mathrm{ha}$, respectively) as compared to Kufri Bahar and Kufri Surya.

Correlation studies in potato: LAI of potato crop was significantly negatively correlated with maximum and minimum temperature. LAI (0.59) was positively correlated with evening relative humidity (Table 6). The accumulation of dry matter (0.66 and 0.52 ) showed positive correlation with wind speed and rainy days. The well distributed rain favoured the dry matter accumulation. Tuber yield $(0.78,0.80$ and 0.92$)$ was significantly positively correlated with evening relative humidity, rainfall and rainy days whereas it was negatively correlated with wind speed $(-0.81)$, sunshine hours $(-0.80)$ and evaporation $(-0.66)$. The vegetative growth do not prefer higher temperatures as the number of leaves per plant $(-0.62$ and -0.60$)$ were significantly negatively correlated with maximum and minimum temperatures whereas significant positive correlation with wind speed (0.57). The plant height was significantly positively correlated with wind speed $(0.61)$, rainfall $(0.50)$ and rainy days (0.53).

\section{Conclusion}

It may be concluded that, the planting dates significantly influenced the different growth and yield attributes of potato. The highest tuber yield $(20810.45 \mathrm{~kg} / \mathrm{ha})$ was obtained in $3^{\text {rd }}$ Week of October (22 ${ }^{\text {th }}$ October) in 2016-17 due to more plant height; more number of leaves per plant which leads to more biomass accumulation. However in 2016-17, heavy rainfall at the time of tuber bulking stage leads to reduction in tuber yield. Among the varieties, tuber yield was significantly higher in Kufri Pushkar (21478.06 kg/ha) as compared to Kufri Bahar (17432.26 kg/ha) and Kufri Surya (15378.11 kg/ha). Plant height (0.61), number of leaves per plant (0.57) and dry matter (0.66) were significantly positively correlated whereas tuber yield $(-0.81)$ was significantly negative correlated with wind speed. Evening relative humidity was also positively correlated with LAI $(0.59)$ and tuber yield $(0.78)$ of potato.

\section{REFERENCES}

1. Ezekiel, R. and Bhargava, S. C. (1997). The influence of high temperature on growth and yield of early potatoes under short day condition. Indian J. of Plant Physiol. 2: 93-97.

2. FAOSTAT (2014). Food and agricultural commodities production. Food and Agriculture Organisation of the United Nations.

3. Feustel, I. C. (1987). Miscellaneous products from potatoes. p 727-746. In Talburt, W. F., O. Smith (eds.) Potato Processing, $4^{\text {th }}$ Ed., Van Nostrand, New York.

4. Haverkort, A. J. (1990). Ecology of potato cropping systems in relation to latitude and altitude. Agric. Syst. 32: 251-272.

5. Hirpa, A., Meuwissen, M. P. M., Tesfaye, A., Lommen, W. J. M., Lansink, A. O., Tsegaye, A. and Struik, P. C. (2010). Analysis of Seed Potato Systems in Ethiopia. American Potato Res. J. 87: 537-552.

6. Indiastat (2018). Ministry of Agriculture and Farmers welfare, Govt. of India. http://www.indiastat.com/ table/agriculture/areaundercropsON154 \& ON1601.

7. Khan, A. A., Jilani, M. S., Khan, M. Q. and Zakhir M. (2011). Effect of seasonal variation on tuber bulking rate of potato. J. Animal Plant Sci., 21(1): 31-37.

8. Modisane, P. C. (2007). Yield and quality of potatoes as influenced by calcium nutrition, temperature and humidity. M.Sc. Thesis submitted to University of Pretoria, South Africa.

9. Perumal, N. K. (1981). Influence of date of planting on the growth, development and yield of potato. $J$. Root Crops., 7(1,2): 33-36.

10.Talburt, W. F. (1987). History of potato processing. p 1-10. In Talburt, W. F., and O. Smith (eds.) Potato Processing, $4^{\text {th }}$ ed., Van Nostrand, New York.

11.Thongam, B., Kadam A. S., Singh, A. A and Singh Y. S. (2017). Influence of planting dates on growth and yield of potato (Solanum tuberosum L.). J. Pharmacognosy Phytochem., 6(6): 1243-1246. 